\title{
PERLINDUNGAN HUKUM TERHADAP PERUSAHAAN FACTOR DALAM PENAGIHAN PIUTANG DAGANG PADA TRANSAKSI ANJAK PIUTANG (FACTORING)
}

\author{
Oleh : \\ I Dewa Ayu Dwi Mayasari ${ }^{1}$
}

\begin{abstract}
Research in connection with jurnal writing thesis takes the theme the protection of the law against companies factor in billing accounts receivable factoring transactions. Problems studied involves two things; the first what factors the company's legal position as a buyer on receivables in factoring and financing institution both what form of legal protection that can be given to companies factor of a possible failure of the trade receivables collection.

This includes research conducted legal research categories, namely normative legal research literature or legal research based on secondary data. The approach used is the approach ot the laws and facts approach. Next to for further analysis techniques use the description legal interpretation techniques based argumentative theory, principles, and concepts relevan laws.

The results showed that the company,s legal position as a purchaser of factoring receivables is very weak and vulnerable than risk the possibility of failure of collection of accounts receivable due to non fulfilment of the achievements by the customer. In this context there is no guarantee of legal protection for the company for the payment or refund factor its receivables in full.

The next from legal protection that can be given to the factor as a buyer of receivables is; a) apply the type of recourse factoring in the factoring agreement with the burden of responsibility is on the client in case of failure of collection of accounts receivable, $b$ ) implement a system of personal/corporate guarantees, and c) apply the prudential banking principles.
\end{abstract}

Keywords : Standing, Legal Protection, Client, Company Factor, Factoring.

\section{Pendahuluan}

1. Latar Belakang Masalah

Salah satu aspek yang penting dalam pembangunan hukum di Indonesia adalah tentang perlindungan hukum bagi setiap warga Negara Indonesia. Isu ini tidak kalah pentingnya dengan isu keadilan, kepastian hukum dan penegakan hukum yang sering menjadi bahan kajian dari para teoritisi maupun praktisi hukum.

Salah satu tujuan Negara Indonesia adalah melindungi segenap bangsa
Indonesia. Seperti dikemukakan oleh Moch. Koesnoe, salah satu nilai dasar yang bersumber pada pokok-pokok pikiran Pembukaan Undang-Undang Dasar Negara Republik Indonesia Tahun 1945 adalah, tata hukum berwatak mengayomi atau melindungi. Mengayomi atau memberi pengayoman menurut konsep Jawa terkandung sesuatu "ayom", suasana sejuk dan aman damai bagi yang dilindungi.

Perlindungan hukum yang dimaksud dalam konteks kajian ini 
adalah perlindungan hukum menyangkut hubungan bisnis (hubungan perjanjian) antara Perusahaan Anjak Piutanng dengan pihak Klien dalam perjanjian Anjak Piutang (Factoring). Fokus perhatiannya disini adalah perlindungan hukum terhadap perusahaan Anjak Piutang (Factoring) sebagai pembeli piutang dagang.

Mengacu pada ketentuan Pasal 1 angka 6 PerPres RI Nomor 9 Tahun 2009 tentang Lembaga Pembiayaan, yang dimaksud Anjak Piutang (Factoring) adalah kegiatan pembiayaan dalam bentuk pembelian piutang dagang jangka pendek suatu perusahaan berikut pengurusan atas piutang tersebut.

Dalam Lembaga Pembiayaan Anjak Piutang, ada pihak Perusahaan Anjak Piutang (Factor) selaku pembeli piutang. Selanjutnya ada pihak Klien yang mempunyai tagihan (piutang) terhadap Customer (debitur). Tagihan (piutang) Klien tersebut kemudian dijual (dialihkan) kepada perusahaan Anjak Piutang (Factor). Dalam konstruksi Anjak Piutang, mengingat tagihan (piutang) tersebut sudah dijual (dialihkan) kepada Factor, maka selanjutnya pihak Factor yang berhak menagih piutang tersebut terhadap Customer.

Lembaga Pembiayaan Anjak Piutang termasuk kategori bisni yang berisiko tinggi, karena tidak ada jaminan pengembalian atau pembayaran piutang tersebut dari Customer terhadap Perusahaan Anjak Piutang (Factor). Kemungkinan gagalnya penagihan piutang oleh Factor terhadap Customer bisa terjadi, baik karena Customer tidak mampu atau tidak mau membayar piutang yang sudah dialihkan tersebut.

Bila benar terjadi adanya kegagalan penagihan piutang tersebut oleh Factor baik seluruhnya maupun sebagian, maka yang akan menanggung risikonya adalah pihak Factor sendiri, terlebih-lebih yang disepakati adalah Without Recourse Factoring (Anjak Piutang tanpa jaminan dari penjual piutang) oleh para pihak dalam perjanjian Factoring.

Anjak piutang tanpa jaminan dari penjual piutang (Without Recourse Factoring) merupakan kegiatan Anjak Piutang dimana perusahaan Factor bertanggungjawab atas segala risiko tidak tertagihnya piutang, artinya apabila terjadi kegagalan dalam penagihan piutang dagang merupakan tanggung jawab pihak perusahaan Factor sendiri. Sementara pihak penjual piutang (Klien) tidak lagi bertanggung jawab akan hal itu. $^{1}$

Dalam posisi perusahaan Anjak Piutang (Factor) seperti itu, maka kedudukannya sangat rentan dan lemah, karena tidak ada jaminan perlindungan hukum dari kemungkinan gagalnya penagihan piutang tersebut. Kegagalan penagihan piutang tersebut dapatberakibat perusahaan Anjak Piutang menanggung kerugian. Dari segi bisnis ini memang suatu risiko Factor, tetapi persoalannya yang tidak bisa diterima ketika Customer beritikad tidak baik dengan sengaja tidak

Miranda Nasihin, 2012, Segala Hal Tentang Hukum Lembaga Pembiayaan, Buku Pintar, Yogyakarta, hlm.64. 
mau memenuhi kewajibannya dalam perjanjian Anjak Piutang yang sudah disepakati.

Merunut dari sejarah hukum, suatu Negara semestinya mulai memperhatikan mengenai perlindungan tenaga kerja, perlindungan konsumen, dan termasuk pula perlindungan terhadap pihak-pihak yang terlibat dalam suatu transaksi bisnis yang notabene sudah diikat oleh suatu kontrak atau perjanjian.

Hubungan hukum antara pihakpihak yang terlibat dalam Anjak Piutang (Factoring) adalah perjanjian yang didasarkan kepada azas kebebasan berkontrak sebagaimana yang disebutkan pada Pasal 1338 KUH Perdata. Dengan dasar azas kebebasan berkontrak ini, perjanjian mempunyai kekuatan mengikat untuk dipatuhi oleh pihak-pihak. Dalam konteks ini sesungguhnya pihak Factor dapat menuntut pelunasan prestasi jika Customer wanprestasi. Namun pada kenyataannya Factor dihadapkan pada situasi sulit ketika itikad baik dari Customer tidak ada untuk memenuhi prestasinya.

Hukum yang ideal adalah hukum yang dapat memberikan keadilan, kepastianhukum, danperlindungan hukum bagi setiap orang. Sudah seharusnya pula hukum dapat memberikan jaminan perlindungan kepada para pihak, terutama kepada perusahaan Anjak Piutang (Factor) sebagai pembeli piutang yang tingkat risikonya sangat tinggi dari kemungkinan adanya kegagalan penagihan piutang.

\section{Rumusan Masalah}

Berdasarkan pada latar belakang masalah sebagaimana yang disampaikan, maka dapat ditarik 2 (dua) masalah pokok yang akan dibahas dalam penulisan jurnal ini, yaitu;

1. Bagaimana kedudukan hukum perusahaan Anjak Piutang (Factor) sebagai pembeli piutang dalam Lembaga Pembiayaan Anjak Piutang?

2. Apa bentuk perlindungan hukum yang dapat diberikan kepada perusahaan Anjak Piutang (Factor) dari kemungkinan adanya kegagalan penagihan piutang dagang?

\section{Tujuan Penelitian}

Tujuan penelitian ini pada dasarnya untuk memahami kedudukan hukum perusahaan Anjak Piutang (Factor) sebagai pihak pembeli piutang dalam Lembaga Pembiayaan Anjak Piutang sehubungan dengan adanya kemungkinan kegagalan penagihan piutang dagang oleh Factor terhadap Customer.

Selanjutnya guna memperluas jangkauan penelitian, maka penelitian ini juga dimaksudkan untuk memahami bentuk perlindungan hukum yang dapat diberikan kepada perusahaan Anjak Piutang (Factor) dari kemungkinan adanya kegagalan penagihan piutang dagang.

\section{Metode penelitian}

Jenis penelitian dalam kaitannya dengan tulisan ini adalah jenis penelitian hukum yang sifatnya Normatif, yaitu penelitian hukum kepustakaan atau 
penelitian hukum yang didasarkan pada data sekunder. ${ }^{2}$ Sementara pendekatan yang digunakan dalam penelitian ini adalah pendekatan perundang-undangan (the statue approach), dan pendekatan fakta (the fact approach). Permasalahan penelitian dikaji dengan mempergunakan teknik interpretasi hukum dengan uraian argumentatif yang didasarkan pada teoriteori, azas-azas, dan konsep hukum yang berkaitan dengan penulisan jurnal ini.

Penelitian hukum ini mempergunakan bahan hukum primer, bahan hukum sekunder, dan bahan hukum tersier. Dimana telah dikumpulkan melalui studi dokumen yang kemudian dimaksud dengan menggunakan teknik deskripi, interpretasi, evaluasi, dan argumentasi.

\section{Hasil dan pembahasan}

\section{Konsep Dasar Perlindungan Hukum}

Salah satu wujud dari implementasi peran hukum dalam kegiatan usaha diantaranya tercermin dalam wujud perlindungan hukum terhadap pihakpihak yang terlibat dalam kegiatan usaha tersebut, baik perlindungan terhadap para pelaku usaha maupun perlindungan terhadap para pengguna jasa atau produk yang dihasilkannya. Perlindungan terhadap para pelaku usaha antara lain dapat dilihat dari adanya jaminan yang diberikan oleh pemerintah terhadap aktivitas yang mereka jalankan dan perlindungan terhadap aset-aset usaha

Soerjono Soekanto, 1985, Penelitian Hukum Normatif Suatu Tinjauan Singkat, CV Rajawali, Jakarta, hlm. 15 . mereka. Demikian halnya perlindungan yang harus dirasakan oleh para pengguna produk dan jasa yang disediakan oleh para pelaku usaha. ${ }^{3}$

Secara tekstual perlindungan hukum merupakan perlindungan dengan menggunakan sarana hukum atau perlindungan yang diberikan oleh hukum. Dalam bahasa Inggris perlindungan hukum disebut dengan "legal protection", sedangkan dalam bahasa Belanda "rechsbecherming". Perlindungan hukum terdiri dari dua kata, yaitu "perlindungan" dan "hukum". Perlindungan hukum timbul karena adanya hubungan hukum antara seseorang dengan orang lain atau dengan badan hukum. Oleh karenanya, hubungan hukum adalah pola pertama dalam rangka memberikan sebuah perlindungan hukum terhadap seseorang. ${ }^{4}$

Beberapa sarjana ada yang memberikan pengertian tentang perlindungan hukum sebagai berikut ;

MenurutSatjiptoRaharjo,perlindungan hukum adalah:

"Memberikan pengayoman terhadap hak asasi manusia (HAM) yang dirugikan orang lain dan perlindungan itu diberikan kepada masyarakat agar dapat menikmati semua hak-hak yang diberikan oleh hukum." ${ }^{5}$

Maria Theresia Geme mengartikan perlindungan hukum adalah :

Johan Arifin, dkk, 2010, Perlindungan Hukum Nasabah Lembaga Keuangan Mikro Syari'ah, Studi Terhadap Nasabah BMT di Kota Semarang, Walisongo Press, Semarang, hlm.17.

Ibid.

Satjipto Raharjo, 2000, Ilmu Hukum, PT. Citra Aditya Bakti, Bandung, hlm.54. 
"Berkaitan dengan tindakan Negara untuk melakukan sesuatu dengan (memberlakukan hukum Negara secara eksklusif) dengan tujuan untuk memberikan jaminan kepastian hakhak seseorang atau kelompok orang"' ${ }^{6}$

Definisi perlindungan dalam definisi diatas, kurang lengkap karena bentuk perlindungan dan subjek yang dilindungi berbeda antara satu dengan lainnya

Dalam perkembangan perlindungan hukum selanjutnya muncul beberapa aliran atau mazhab besar yang mempengaruhi perkembangan hukum, misalnya aliran hukum alam, mazhab sejarah, mazhab positivisme, aliran sociological yurisprudensi, dan critical legal studies (gerakan hukum kritis). ${ }^{7}$ Aliran-aliran atau mazhab tersebut merupakan inti dari prinsip perlindungan hukum bagi setiap warga Negara dan tidak terpisahkan dari tujuan dibentuknya Negara Kesatuan Republik Indonesia sebagaimana dirumuskan pada Alinea IV UUD 1945, yang antara lain menyebutkan: "Kemudian dari pada itu untuk melindungi segenap bangsa Indonesia dan seluruh tumpah darah Indonesia...........Maka disusunlah kemerdekaan Indonesia dalam suatu Undang-Undang Dasar......"

Jika dirunut maka perlindungan hukum menjadi penting dalam rangka

\footnotetext{
Maria Theresia Geme,2012, “Perlindungan Hukum terhadap Masyarakat Hukum Adat dalam Pengelolaan Cagar Alam Watu Ata Kabupaten Ngada, Provinsi Nusa Tenggara Timur, disertai Program Doktor Ilmu Hukum Fakultas Hukum Universitas Brawijaya Malang, hlm.99.

Johan Arifin, dkk, Op. Cit, hal.
}

pemenuhan hak-hak seseorang dalam hubungannya dengan orang lain. ${ }^{8}$ Dalam konteks perlindungan perusahaan Factor, maka yang dilindungi adalah kepentigan Factor dalam kaitannya sebagai pembeli piutang dalam mendapatkan jaminan hak pengembalian atau penagihan piutang terhadap Customer.

$$
\text { Perlindungan hukum adalah }
$$

perlindungan dengan sarana hukum. Tidak semua kepentingan peerlu dilindungi hukum. Kepentingan yang dilindungi hukum adalah kepentingan yang dinyatakan sebagai hak. ${ }^{9}$ Dalam konteks perlindungan hukum terhadap Factor adalah perlindungan kepentingan yang berupa hak Factor untuk mendapatkan pengembalian piutangnya dari Customer.

Hukum sebagai perlindungan kepentingan manusia berbeda dengan norma-norma yang lain. Karena hukum itu berisi perintah dan/atau larangan, serta membagi hak dan kewajiban. ${ }^{10}$ Sudikno Mertokusumo mengemukakan tidak hanya tentang tujuan hukum, tetapi juga tentang fungsi hukum dan perlindungan hukum. ia berpendapat bahwa :

$$
\begin{array}{lcr}
\text { "Dalam fungsinya } & \text { sebagai } \\
\text { perlindungan } & \text { kepentingan } & \text { manusia }
\end{array}
$$

Johan Arifin, dkk, Op. Cit, hlm.16.

Moelyoto, Perlindungan Hukum Terhadap Pemiliik Tanah Dalam Pelaksanaan Hukum Tata Negara Darurat Karena Peristiwa G30S/PKI (Studi Kasus di Jawa Tengah : dalam Bunga Rampai Pemikiran Hukum di Indonesia), FH. UII Press, Yogyakarta, hlm.230.

10 H. Salim HS dan Erlies Septiana Nurbani,2013, Penerapan Teori Hukum Pada Penelitian Tesis dan Disertasi, PT Raja Grafindo Persada, Jakarta hlm.269. 
hukum mempunyai tujuan. Hukum mempunyai sasaran yang hendak dicapai. Adapun tujuan pokok hukum adalahmenciptakan tatananmasyarakat yang tertib, menciptakan ketertiban dan keseimbangan. Dengan tercapainya ketertiban di dalam masyarakat diharapkan kepentingan manusia akan terlindungi. Dalammencapai tujuannya itu hukum bertugas membagi hak dan kewajiban antar perorangan di dalam masyarakat, membagi wewenang dan mengatur cara memecahkan masalah hukum serta memelihara kepastian hukum. ${ }^{11}$

\section{Bentuk Perlindungan Hukum}

Hukum berfungsi untuk kepentingan manusia. Agar kepentingan manusia dapat dilindungi, maka hukum mesti dijalankan. Pelaksanaan hukum dapat berlangsung secara normal, damai, tetapi bisa juga terjadi karena adanya pelanggaran hukum. Adanya Pelanggaran hukum tersebut dapat timbul ketika subyek hukum tidak mampu melaksanakan kewajiban yang semestinya dilakukan atau karena melanggar hak-hak subyek hukum lain. Subyek hukum yang dilanggar hakhaknya harus mendapatkan perlindungan hukum. ${ }^{12}$

"De mogelijkheden van rechtsbescherming zijn van belang wanneer de overhead iets heft gedaan of nagelaten of voornemens is bepaalde handelingen te verrichten en be paalde

11 Sudikno Mertokusumo, 1999, Mengenal Hukum Suatu Pengantar, Liberty, Yogyakarta, hlm.71.

12 Ibid, hlm.140. personen of groepen zich daardoor gegriefd achten. ${ }^{13} \quad$ (Memberikan perlindungan hukum akan penting ketika pemerintah bermaksud untuk melakukan atau tidak melakukan tindakan tertentu terhadap sesuatu, yang oleh karena tindakan atau kelalaiannya itu melanggar hak-hak orang atau kelompok tertentu).

Secara teoritis, bentuk perlindungan hukum dibagi menjadi dua bentuk yaitu ;

1. Perlindungan yang bersifat preventif dan

2. Perlindungan yang bersifat represif. ${ }^{14}$ Pada perlindungan hukum preventif, rakyat diberikan kesempatan untuk mengemukakan pendapatnya ataupun keberatan sebelum suatu keputusan pemerinah mendapat bentuk yang definitif. Dan sebaliknya pada perlindungan hukum yang represif ini bertujuan sebagai penyelesian sengketa. Kedua bentuk perlindungan hukum tersebut bersumber pada pengakuan serta perlindungan hak asasi manusia yang berlandaskan pada prinsip Negara hukum.

Di dalam peraturan perundangundangan telah ditentukan bentuk-bentuk perlindungan yang diberikan kepada masyarakat atas adanya kesewenangwenangan dari pihak lainnya, baik itu penguasa, pengusaha, maupun orang yang

VanDerBurg Fit, etal, 1985, Rechtsbeschermingtegende Overheid, Nigmegen, 1985, hlm.3.

14 Philipus M. Hadjon, 1987, Perlindungan Hukum bagi Rakyat Indonesia, PT Bina Ilmu, Surabaya, hlm.2. 
mempunyai ekonomi lebih baik dari pihak korban. Pada prinsipnya, perlindungan hukum terhadap pihak yang lemah selalu dikaitkan dengan perlindungan terhadap hak-hak pihak yang lemah atau korban. ${ }^{15}$

\section{Perlindungan Hukum Bagi Factor} Dari Kemungkinan Gagalnya Penagihan Piutang Dagang

Setiap bisnis pasti ada risikonya. Hal ini tentu saja benar adanya. Apalagi bisnis mengenai penyediaan dana seperti bisnis Anjak Piutang (Factoring). Terlebih lagi untuk jenis Without Recourse Factoring, dimana perusahaan Factor akan bertanggungjawab atas segala risiko apabila nasabah (Customer) tidak mampu untuk memenuhi kewajibannya.

Pada Without Recourse Factoring, kedudukan Factor sangat krusial dan minimnya perlindungan yang berupa jaminan pengembalian piutang dagang dari Customer. Bila Customer tidak memenuhi kewajibannya, maka risiko sepenuhnya akan dipikul oleh Factor.

Sebagai suatu bisnis, risiko dan kemungkinan kegagalan penagihan piutang dagang tentunya sudah dalam perhitungan bisnis dari Factor, dengan menerima kompensasi berupa fee atau bayaran lainnya. ${ }^{16}$ Namun risiko tersebut tetap sebagai suatu kondisi yang mungkin terjadi dan tidak dapat dihindari oleh Factor.

15 H. Salim HS dan Erlies Septiana Nurbani, Op. Cit, hlm. 265.

16 Munir Fuady, 2006, Hukum tentang Pembiayaan, PT Citra Aditya Bakti, Bandung. hlm.86.
Guna menghindari atau mencegah adanya kerugian bagi Factor dalam hal adanya kegagalan penagihan piutang dagang yang pada dasarnya merupakan hak dari Factor, maka terhadap Factor penting untuk diberikan perlindungan hukum yang memberikan jaminan pengembalian piutang dari Customer.

Hak untuk mendapat pengembalian piutang (hak tagih utang) terhadap Customer timbul dari adanya perjanjian Anjak Piutang. Dalam perjanjian Anjak Piutang, pihak Factor mempunyai sejumlah hak yaitu;

1. Menerima semua dokumen invoice (Faktur) dari klien.

2. Menerima piutang dalam keadaan bersih dan bebas dari segala tuntutan.

3. Melakukan penagihan piutang kepada nasabah (Customer) sesuai syarat pembayaran yang telah ditetapkan antara penjual piutang (Klien) dengan nasabah (Customer). ${ }^{17}$

Hak melakukan penagihan piutang dari Factor lahir dari hubungan hukum perjanjian, yaitu perjanjian Anjak Piutang. Bachsan Mustafa menyatakan bahwa hak itu merupakan kekuasaan, dan kekuasaan itu dapat dipertahankan terhadap setiap orang, artinya setiap orang harus mengakui, menghormati, dan mengindahkan hak itu. ${ }^{18}$

Begitu juga H.J.Mc. Closkey, menegaskan secara umum hak dapat diartikan sebagai klaim atau kepemilikan

Ahmad Muliadi, 2013, Hukum Lembaga Pembiayaan Akademia Permata, Jakarta, hlm.66.

18 Bachsan Mustafa, 2003, Sistem Hukum Indonesia Terpadu, PT Citra Aditya Bakti, Bandung. 
individu atas sesuatu. Seseorang dikatakan memiliki hak jika orang tersebut memiliki klaim untuk melakukan dalam suatu cara tertentu, atau jika orang lain berkewajiban melakukan tindakan dalam suatu cara tertentu kepadanya. ${ }^{19}$

Hak untuk melakukan penagihan piutang oleh Factor terhadap Customer dilindungi oleh hukum. Sebagaimana disampaikan oleh Sudikno Mertokusumo, hak adalah kepentingan hukum yang dilindungi oleh hukum, sedangkan kepentingan adalah tuntutan yang diharapkan untuk dipenuhi. Kepentingan pada hakekatnya mengandung kekuasaan yang dijamin dan dilindungi oleh hukum. ${ }^{20}$ Atas dasar itulah hak melakukan penagihan piutang dari Factor perlu diberikan perlindungan hukum.

Begitu juga menurut Suhardjo, hukum berfungsi mengayomi atau melindungi manusia dalam bermasyarakat dan berbangsa serta bernegara, baik jiwa dan badannya maupun hak-hak pribadinya, yaitu hak asasinya, hakhak kebendaannya, maupun hak-hak perorangannya. ${ }^{21}$

Mengingat risiko gagalnya penagihan piutang terhadap Customer cukup tinggi, terutama dalam hal without recourse Factoring, maka bentuk perlindungan hukum yang dapat diberikan kepada Factor yaitu;

19 H.J.Mc. Closkey dalam John Pieris dan Wiwik Sri Wiarty, 2007, Negara Hukum dan Perlindungan Konsumen Terhadap Produk Kadaluarsa, Pelangi Cendikia, Jakarta.

20 Sudikno Mertokusumo, Loc. Cit.

21 Suhardjo dalam Bachsan Mustafa, Loc. Cit.
1. Penggunaan Recourse Factoring

Guna melindungi Factor, dalam arti memberikan jaminan penagihan piutang dari Customer, maka dalam perjanjian Factoring dapat digunakan atau diterapkan jenis Recourse Factoring, yaitu anjak piutang dimana Klien akan menanggung risiko apabila nasabah (Customer) tidak memenuhi kewajibannya. Jadi perusahaan Factor tidak bertanggungjawab atas piutang yang tidak tertagih dari Customer.

2. Menerapkan Personal/Corporate Guarantee

Mengingat bisnis Factoring rentan risiko, dan bahkan dikatakan sebagai jenis bisnis yang mengandung risiko tinggi terhadap keberhasilan dalam penagihan piutang, maka untuk mengamankan atau melindungi Factor, dapat diterapkan sistem penanggungan (jaminan) utang melalui penerapan Personal maupun Corporate Guarantee.

Sehubungan dengan Personal/ Corporate Guarantee ini, dimana pihak ketiga mengingatkan diri sebagai penanggung atau penjamin tagihan Factor sebagai pihak yang berpiutang. Apabila pihak Customer tidak dapat memenuhi kewajibannya, maka pihak penanggung atau penjamin utang ini akan menanggungnya.

Perihal penanggung atau penjamin utang ini dapat ditemui pengaturannya dalam Kitab Undang-Undang Hukum Perdata (KUHPerdata). Pada ketentuan pasal 1820 KUHPerdata menyatakan bahwa yang dimaksud penanggungan 
adalah suatu perjanjian dengan mana seorang pihak ketiga guna kepentingan si berpiutang mengikatkan diri untuk memenuhi perikatannya si berpiutang, manakala orang ini sendiri tidak memenuhinya. ${ }^{22}$

Dari batasan yang terdapat dalam Pasal 1820 KUH Perdata tersebut dapat diketahui bahwa yang dimaksud dengan penanggung adalah pihak ketiga. Yang dimaksud pihak ketiga dalam hal ini adalah orang secara pribadi atau badan hukum. Manakala yang bertindak selaku penanggung adalah orang pribadi, maka disebut sebagai jaminan pribadi (Personal Guarantee). Apabila yang bertindak sebagai penanggung adalah perusahaan, maka disebut sebagai jaminan perusahaan (Corporate Guarantee). ${ }^{23}$

Perjanjian penanggungan atau penjaminan ini dibuat tersendiri untuk kepentingan Factor, sehingga Factor terjamin penagihan piutangnya terhadap Customer. Penanggungan itu sendiri pada dasarnya merupakan suatu perjanjian yang lahir atau dibuat setelah adanya perjanjian utang piutang.

Perjanjian utang piutang merupakan perjanjian pokok, sedangkan perjanjian penanggungan bersifat sebagai tambahan yang tidak terpisahkan dari perjanjian pokok. Eksistensi perjanjian

22 Y. Sogar Simamora, 2000, Tanggung Gugat Penanggung Personel Guarantee dan Corporate Guarantee; dalam Puspa Ragam Intorinasi Dan Problematika Hukum, Karya Aditama, Surabaya, hlm.68.

23 Mariam Darus Badrulzaman, 1982, Bab 2 Tentang Credit Verband, Gadai, dan Fidusia, Alumni, Bandung, hlm.2. penanggungan bergantung pada perjanjian pokoknya. Perjanjian ini lahir karena adanya perjanjian pokok, dan apabila perjanjian pokok berakhir, kemudian dengan sendirinya penanggungan juga berakhir. Dari karakter yang demikian itu, perjanjian penanggungan dikatakan bersifat accesoir.

Dalam hubungannya dengan perjanjian Factoring, yang disertai adanya perjanjian penanggungan (Personal/Corporate Guarantee), maka pihak penanggung akan membayar utang Customer kepada Factor, manakala Customer wanprestasi, dan pihak Customer harus terlebih dahulu memenuhi kewajibannya dengan terlebih dahulu harta bendanya disita dan dijual untuk melunasi utangnya. Apabila masih ada sisa utang yang belum terbayar, maka kekurangannya akan ditutup oleh penanggung.

Prinsip seperti yang disebutkan diatas bisa dicermati pengaturannya pada ketentuan Pasal 1831 KUH Perdata, yang menerangkan bahwa penanggung tidak wajib membayar kepada kreditur, kecuali jika debitur lalai membayar utangnya, sedangkan benda-benda si debitur ini harus lebih dahulu disita dan dijual untuk melunasi utangnya.

3. Menerapkan Prinsip Kehati-hatian (Prudential Principle)

Penerapan prinsip kehati-hatian ini untuk menghindari risiko yang timbul dikemudian hari atas gagalnya penagihan piutang. Prinsip kehati-hatian dimaksud merupakan tugas Factor untuk bertindak selektif dalam pembelian piutang dengan 
memperhatikan kualitas piutang (tagihan) dan kondisi Customer sebagai debitur.

Hal yang menyangkut kualitas piutang, pihak Factor sebaiknya meneliti secara cermat mengenai keabsahan piutang (Validity of Receivable). Factor dapat meminta Klien untuk memberikan jaminan bahwa piutang yang dijual adalah piutang yang sudah ada. Selain itu, Klien juga harus memberikan jaminan bahwa nilai jumlah piutang oleh Klien telah dihitung dengan benar, dan piutang tersebut bebas dari kemungkinan adanya tuntutan dari pihak ketiga. ${ }^{24}$

Selanjutnya hal yang menyangkut kondisi Customer, penerapan prinsip kehati-hatian dengan menerapkan prinsip 5C (Character, Capacity, Capital, Condition of Economy, dan Collateral), dimana prinsip ini sangat lazim dipraktekan dalam dunia perbankan.

Apa yang dimaksud dengan prinsip

5C tersebut dapat diberikan penjelasan dibawah ini;

\section{Character (Kepribadian)}

Unsur pertama yang dapat diperhatikan oleh Factor sebelum mengambil keputusan untuk membeli atau menerima pengalihan piutang adalah melakukan penilaian atas karakter atau kepribadian dari Customer sebagai debitur. Watak dari Customer yang jelek akan berpengaruh pula terhadap ketataan yang bersangkutan untuk memenuhi kewajibannya.

\section{Capacity (Kemampuan)}

24 Sunaryo, Sunaryo, 2008, Hukum Lembaga Pembiayaan, Sinar Grafika, Jakarta, hlm.89.
Pihak Customer sebagai debitur sangat penting untuk dilihat sejauh mana kemampuan dalam bisnisnya, sehingga bisa diperkirakan pula kesanggupannya untuk melunasi utangnya. Bila kemampuan bisnisnya kecil, sudah pasti harus dipertimbangkan kemampuannya dalam membayar utangnya.

\section{Capital (Modal)}

Aspek permodalan atas usaha yang dijalankan juga merupakan hal yang tidak dapat diabaikan begitu saja. Permodalan Customer sebagai debitur berhubungan erat dengan tingkat kemampuannya untuk membayar utang atau kewajiban-kewajiban lainnya terhadap pihak ketiga.

4. Condition of Economy (Kondisi Ekonomi)

Kondisi perekonomian secara makro maupun mikro merupakan pertimbangan penting yang perlu dicermati sebelum Factor mengambil keputusan untuk membeli piutang. Kondisi perekonomian yang tidak stabil atau pada masa krisis ekonomi, dengan menurunnya daya beli masyarakat akan berpengaruh terhadap kemampuan Customer membayar tagihan-tagihan dari pihak lain.

5. Collateral (Agunan)

Tidak diragukan bahwa Collateral (agunan) merupakan hal yang penting untuk diperhatikan. Factor dapat meminta jaminan kebendaan (agunan) dalam pemenuhan pembayaran tagihan piutang dagangnya. Agunan 
merupakan the last resort bagi Factor, dimana akan direalisasi (dieksekusi) jika Customer betul-betul tidak dapat memenuhi kewajibannya untuk melunasi utangnya.

\section{Penutup \\ 1. Simpulan}

a. Kedudukan hukum perusahaan Anjak Piutang (Factor) sebagai pihak pembeli piutang sangat lemah dan rentan dari risiko kemungkinan gagalnya penagihan piutang yang disebabkan tidak dipenuhinya prestasi oleh pihak Customer. Dalam konteks ini tidak ada jaminan perlindungan hukum bagi perusahaan Anjak Piutang (Factor) atas pembayaran atau pengembalian piutangnya secara penuh.

b. Mengingat lembaga Annjak Piutang merupakan jenis bisnis yang berisiko tinggi, yang rentan terhadap kemungkinan kegagalan piutang, maka bentuk perlindungan hukum yang dapat diberikan terhadap Factor selaku pembeli piutang adalah;

a) Menggunakan atau menerapkan jenis Recourse Factoring dalam perjanjian Anjak Piutang (Factoring). Dengan beban tanggung jawab ada pada Klien manakala terjadi kegagalan penagihan piutang.

b) Menerapkan sistem Personal/ Corporate Guarantee yang melibatkan pihak ketiga sebagai penjamin pelunasan piutang dalam hal terjadi kegagalan penagihan piutang. c) Menerapkan prinsip kehati-hatian (Prudential Principle) untuk menghindari risiko kegagalan penagihan piutang dengan melakukan penilaian secara cermat terhadap kualitas piutang serta kondisi Klien dan Customer dengan menggunakan instrument $5 \mathrm{C}$.

\section{Saran}

a. Agar kedudukan hukum perusahaan Factor sebagai pembeli piutang dagang tidak lemah dan tidak rentan dari risiko terjadinya kegagalan penagihan piutang dagang yang berujung pada kerugian Factor, maka untuk memberikan perlindungan hukum terhadap Factor, maka dalam perjanjian Anjak Piutang (Factoring) harus ada jaminan pengembalian atau pelunasan piutang dagang secara penuh oleh Customer.

b. Mengingat bentuk perjanjian Anjak Piutang (Factoring) berbentuk perjanjian Standar (Perjanjian Baku), maka pihak-pihak yang terlibat dalam perumusan Klausul-Klausul perjanjian tersebut hendaknya memperhatikan ketentuan UndangUndang (Pasal 18 Undang-Undang Perlindungan Konsumen), dalam rangka mewujudkan perjanjian Anjak Piutang yang memenuhi rasa keadilan, kepastian hukum, serta perlindungan hukum bagi kepentingan para pihak. 


\section{DAFTAR PUSTAKA}

Ahmad Muliadi, 2013, Hukum Lembaga Pembiayaan Akademia Permata, Jakarta.

Bachsan Mustafa, 2003, Sistem Hukum Indonesia Terpadu, PT. Citra Aditya Bakti, Bandung.

H Salim HS dan Erlies Septiana Nurbani, 2013, Penerapan Teori Hukum Pada Penelitian Tesis dan Disertasi, PT. Raja Grafindo Persada, Jakarta.

John Pieris dan Wiwik Sri Wiarty, 2007, Negara Hukum dan Perlindungan Konsumen Terhadap Produk Kadaluarsa, Pelangi Cendikia, Jakarta.

Johan Arifin, dkk, 2010, Perlindungan Hukum Nasabah Lembaga Keuangan Mikro Syari'ah, Studi Terhadap Nasabah BMT di Kota Semarang, Walisongo Press, Semarang.

Maria Theresia Geme,2012, "Perlindungan Hukum terhadap Masyarakat Hukum Adat dalam Pengelolaan Cagar Alam Watu Ata Kabupaten Ngada, Provinsi Nusa Tenggara Timur, disertaiProgram Doktor Ilmu Hukum Fakultas Hukum Universitas Brawijaya Malang.

Mariam Darus Badrulzaman, 1982, Bab 2

Tentang Credit Verband, Gadai, dan Fidusia, Alumni, Bandung.

Miranda Nasihin, 2012, Segala Hal Tentang

Hukum Lembaga Pembiayaan, Buku Pintar, Yogyakarta.

Moelyoto, Perlindungan Hukum Terhadap

Pemiliik Tanah Dalam Pelaksanaan Hukum Tata Negara Darurat Karena Peristiwa G30S/PKI (Studi Kasus di Jawa Tengah : dalam Bunga Rampai
Pemikiran Hukum di Indonesia), FH. UII Press, Yogyakarta.

Munir Fuady, 2006, Hukum tentang Pembiayaan, PT. Citra Aditya Bakti, Bandung.

Philipus M. Hadjon, 1987, Perlindungan Hukum bagi Rakyat Indonesia, PT. Bina Ilmu, Surabaya.

Ridwan Khairandy, Politik Hukum Ekonomi Indonesia Dalam Menghadapi Globalisasi Ekonomi Dan Hukum, dalam: Retrospeksi Terhadap Masalah HUkum dan Kenegaraan, FH. UII Press, Yogyakarta.

Satjipto Raharjo, 2000, Ilmu Hukum, PT. Citra Aditya Bakti, Bandung.

Soekanto, 1985, Penelitian Hukum Normatif Suatu Tinjauan Singkat, CV. Rajawali, Jakarta.

Sudikno Mertokusumo, 1999, Mengenal Hukum Suatu Pengantar, Liberty, Yogyakarta.

Sunaryo, 2008, Hukum Lembaga Pembiayaan, Sinar Grafika, Jakarta.

Van Der Burg Fit, etal, 1985, Rechtsbeschermingtegende Overheid, Nigmegen.

Y. Sogar Simamora, 2000, Tanggung Gugat Penanggung Personel Guarantee dan Corporate Guarantee; dalam Puspa Ragam Intorinasi Dan Problematika Hukum, Karya Aditama, Surabaya.

\section{BIODATA}

Nama : I Dewa Ayu Dwi Mayasari

Alamat : J1. Tukad Jinah Blok E/10

Panjer - Denpasar

Bekerja : Belum Bekerja

HP : 081805387866

e-mail 